\title{
O POPULISMO NO BRASIL (1985-2019) \\ Um velho conceito a partir de uma nova abordagem
}

\section{Paolo Ricci (1) (iD)}

E-mail: paolo.ricci@usp.br

\section{Mauricio Izumi ${ }_{(2)}$}

E-mail: mauricioizumi@hotmail.com

\section{Davi Moreira ${ }_{3)}$}

E-mail: davi.moreira@gmail.com

(1)Departamento de Ciência Política da USP, São Paulo - SP, Brasil.

(2) Departamento de Ciências Sociais da UFES, Vitória - ES.

(3) Centro Brasileiro de Análise e Planejamento (Cebrap), São Paulo - SP.

DOI: $10.1590 / 3610707 / 2021$

\section{Introdução}

O populismo está na ordem do dia. A Europa vive uma onda de crescente consenso entre os partidos populistas (Taggart, 2017; Van Kessel, 2015). A heterogeneidade e amplitude do fenômeno residem na constatação de que tais partidos não se acomodam apenas na direita (Mudde, 2017a), mas pertencem também à esquerda (Katsambekis e Kioupkiolis, 2019). Os Estados Unidos não fogem ao script. O sucesso de Donald Trump nas eleições de 2016 tem contribuído para esquentar o debate. Seria ele um líder populista? (Oliver e Rahn, 2016). Por sua vez, a América Latina é terra fértil para se observar o fenômeno. Frequentemente evoca-se alguma liderança populista para retratar a realidade latino-americana, das mais recentes, como Hugo Chaves (Hawkins, 2009)

Artigo recebido em: 20/05/2020

Aprovado em: 12/02/2021 e de países andinos em geral (De La Torre, 2009) aos mais distantes, como Getúlio Vargas e Juan Perón (Weyland, 2001). Tais exemplos encontram respaldo também na Ásia e na Oceania (Moffitt, 2015).

A partir deste cenário global, cabe a pergunta: como interpretar o caso brasileiro? Apesar de ser reconhecida a importância do populismo na história do país, o conhecimento a seu respeito ainda é nebuloso. A razão disso está na grande fragmentação das abordagens. Os estudiosos, em sua maioria, adotam a terminologia da literatura internacional que distingue entre um populismo clássico dos anos 1950 - de Getúlio Vargas, Adhemar de Barros, Jânio Quadros, Miguel Arraes e Leonel Brizola, entre outros - e o populismo neoliberal de Fernando Collor de Mello (1990-1992) (Dagnino, 1994; Cammack, 2000; Panizza, 2000; Ruth-Lovell, 2018).

A vitória eleitoral de Jair Bolsonaro em 2018 reacendeu o debate sobre a existência de um novo populismo, desta vez com cara de direita (Codato et al., 
2018; Tamaki e Fuks, 2020) ou, mais enfaticamente, com características pós-fascistas (Finchelstein, 2019). Contudo, a ausência de rigor metodológico e a ênfase sobre apenas um recorte temporal do populismo no Brasil - o carisma de Vargas, fator mobilizador das massas, ou a crítica ferrenha às elites políticas estatais de Collor - não nos permite ter um quadro completo do fenômeno.

O propósito desse artigo é superar explicaçôes multifacetadas e recortadas para oferecer uma interpretação unitária do populismo em todos os presidentes brasileiros desde a redemocratização (1985-2019). Diante de tal desafio, a clareza conceitual sobre o populismo é o primeiro passo, indispensável a uma pesquisa cujo propósito é a generalização (Goertz, 2006).

O populismo sempre foi um conceito em disputa. Como detalharemos na próxima seção, este artigo adota a abordagem ideacional, segundo a qual o populismo é a expressão de um discurso político que enfatiza a disputa entre dois grupos homogêneos e antagônicos: o povo "puro" e a elite "corrupta" (Hawkins e Kaltwasser, 2017). Essa perspectiva tem suas origens nos trabalhos pioneiros de Ernesto Laclau (1977; 2005) e evoluiu na literatura para um consenso amplo em torno da percepção de que o estudo do populismo deve enfatizar o dualismo, a contraposição e a dicotomia entre dois grupos.

Esclarecido o propósito do artigo, respondemos à seguinte pergunta: quão populistas são os presidentes brasileiros? Para tanto, realizamos uma análise empírica que mensura o nível de populismo dos presidentes a partir de seus pronunciamentos oficiais. Analisamos 5.818 discursos presidenciais entre 1985 e 2019. Os achados mostram que Collor, Lula e Bolsonaro são presidentes populistas quando comparados a seus pares. Além de apresentar as nuances entre eles, os resultados são discutidos considerando a relação entre populismo e democracia. Se para alguns o populismo é um tipo de desfiguração da política democrática (Urbinati, 2013) que pode declinar para formas autoritárias, há quem defenda que o perigo é aparente e longe de se concretizar em democracias consolidadas (Weyland, 2020). O tema é mais do que oportuno, dada a presente conjuntura do Brasil. Antecipamos nossa conclusão sobre o ponto: por si só, o populismo no Brasil não constitui uma ameaça real à democracia.

\section{O que é populismo?}

Em seu livro clássico sobre a democracia, $O$ populismo na politica brasileira, de 1945, Francisco Weffort afirma que o populismo "é, no essencial, a exaltação do poder público; é o próprio Estado colocando-se através do líder, em contato direto com os indivíduos reunidos na massa" (Weffort, 1989: 28). Ele acrescenta: "o populismo é sempre uma forma popular de exaltação de uma pessoa na qual esta aparece como a imagem desejada para o Estado" (Weffort, 1989: 36). O carisma do líder e a massa unificada, identificada pelo autor na população urbana, são as expressóes deste populismo "clássico" (Saes, 1994). Clássico no sentido de pertencer a uma abordagem que pensa a categoria do populismo dentro de uma teoria das relaçôes sociais. ${ }^{1}$ Aqui, o populismo se configura como conceito amplo, cumulativo, que se relaciona com distintas teorias, como as do líder carismático, da modernização, do desenvolvimentismo e da mobilização popular (Weyland, 2001). ${ }^{2}$

Os anos 1990 estimularam uma redefinição daquele populismo que enfatizava a dimensão do controle do Estado sobre a massa de trabalhadores. É a fase do neopopulismo, que se caracterizava pelo surgimento de novos líderes populistas latino-americanos, como Carlos Menem na Argentina, Alberto Fujimori no Peru, Fernando Collor no Brasil e Abdalá Bucaram no Equador. Há duas dimensóes que descreveriam esta nova fase do populismo. Por um lado, a dissonância em relação às características socioeconômicas típicas do populismo clássico. Se este último atribuía centralidade aos programas econômicos de redistribuição (Industrialização de Substituição de Importações ou ISI), o neopopulismo adotava um forte discurso antiestatizante e de cunho neoliberal (Gomes, 1996). Por outro lado, ainda que se reiterasse a centralidade do líder que dialogava com a massa popular, estas novas lideranças estariam menos dispostas a criar instituiçóes e organizaçôes (Weyland, 2001).

A partir dos anos 1990, cada vez mais os autores abandonaram a velha contraposição entre populismo clássico e "novo" para refletir sobre os "mecanismos 
concretos através dos quais os seguidores são mobilizados" (De La Torre, 2003:64). ${ }^{3}$ No Brasil, na mesma época, vários estudiosos passaram a desqualificar o uso do termo. Sobretudo, questionou-se a ideia de um político que se comprometia com e apelava às massas urbanas, manipulando-as ou, ainda, de um controle absoluto do Estado sobre elas (Gomes, 2015). Neste sentido, recusava-se radicalmente a ideia de uma classe trabalhadora passiva e de um Estado todo-poderoso que impóe suas decisóes.

Em uma reconstrução minuciosa das várias correntes de pensamento, Jorge Ferreira sentenciava que "o populismo parece estar em colapso" (Ferreira, 2001). Contudo, enquanto a crítica parece ter enterrado o uso do conceito entre os estudiosos no Brasil, no campo internacional os pesquisadores têm se dedicado a um envolvente debate epistemológico sobre a definiçãa conceitual de populismo (Bonikowski e Gidron, 2016). O ponto de partida pode ser encontrado na "teoria do discurso" de Ernesto Laclau, considerado o decano dos estudos do populismo. ${ }^{4}$ Concebendo o antagonismo político, sobretudo, como princípio fundamental da política, Laclau compreende o populismo como uma forma de moldar opinióes coletivas. Este não é o lugar de detalhar as diferentes interpretaçóes do autor. Basta reconhecer que sua abordagem representa o ponto de partida das discussōes atuais sobre populismo. A questão é que, reconhecida sua importância, no trabalho de Laclau o populismo assume contornos mais amplos, incorporando todas as formas de dualismo e tornando-o abstrato demais para ser objeto de uma análise empírica rigorosa (Mudde e Kaltwasser, 2012).

No campo da pesquisa empírica, cabe esclarecer que o debate atual gira em torno de pelo menos três abordagens. ${ }^{5}$ A abordagem econômica enfatiza as políticas adotadas pelos governos visando o favorecimento do crescimento e a distribuição de renda, mas sem levar em conta os riscos inflacionários e deficitários (Dornbusch e Edwards, 1991; Acemoglu, et al., 2013). O problema desta vertente é não fornecer critérios claros para conceituar o populismo e, sobretudo, limitar o fenômeno à atuação de governos esquerdistas, mais presentes na América Latina (Kaltwasser et al., 2017).

Alternativamente, o populismo é pensado como estratégia política, valorizando a relação quase-direta entre líderes populistas e massa de seguidores (Weyland,
2001). A questáo, aqui, é entender como um ator político, seja partido ou político individual, obtém o apoio do cidadáo comum (Weyland, 2017). Nesta perspectiva, o problema é dar ênfase a um aspecto do populismo - o aspecto carismático da liderança -, desconsiderando outras dimensóes (Mudde, 2007).

Por fim, há a abordagem ideacional, que ganhou muitos adeptos nos últimos anos. Aqui, o elemento central é o papel exercido pelas ideias. Em particular, argumenta-se que o caráter populista dos políticos (e, por extensão, dos partidos) resulta da expressão de uma disputa entre a vontade do homem (do povo) de bem - o homem comum - e uma elite má, conspiradora e corrupta (Hawkins e Kaltwasser, 2017; 2018). Tais ideias seriam um dos fatores mobilizadores das pessoas e de suporte para lideranças e partidos populistas. ${ }^{6}$ Neste artigo, adotamos esta abordagem por duas razóes principais. Por um lado, ela é útil para operacionalizar o conceito de populismo. Isso aparece com clareza na definiçáo a seguir:

uma ideologia thin que considera a sociedade separada em dois campos homogêneos e antagônicos, 'o povo puro' versus 'a elite corrupta', e que argumenta que a política deve ser uma expressão do volonté générale (vontade geral) do povo. (Mudde e Kaltwasser, 2017 p.6)

Aqui, emerge um "núcleo duro", um denominador comum (Rooduijn, 2014) capaz de garantir um consenso mínimo em torno do conceito, permitindo análises no tempo e no espaço. Trata-se de duas palavras-chave: o povo e a elite. Náo há mal-entendidos aqui. As definiçóes enfatizam a posição central do povo frente uma elite percebida negativamente. O povo é geralmente visto como uma entidade homogênea, associada ao homem comum, bom e honesto. O significado do termo the people é amplo: indica o povo, mas também é usado no sentido de comunidade nacional. $\mathrm{Na}$ Europa, por exemplo, o discurso populista valoriza as próprias comunidades nacionais perante aquela dos imigrantes, inclusive os de primeira geraçấo, que continuam sendo discriminados na categoria de outros (Mudde, 2007).

Por sua vez, a elite é percebida como má, conspiradora e corrupta, incapaz de conviver em harmonia com 
a gente comum. O termo elite também é tratado de forma ampla; subentende grupos mais ou menos específicos - os políticos, os intelectuais, a mídia, o judiciário - ou, de forma mais geral, aqueles que gozam de certas vantagens em relação ao povo. No discurso de Hugo Chaves, por exemplo, emerge a luta do povo (the people) contra as forças imperialistas opressivas (Hawkins, 2010). Matteo Salvini, leader da Liga Norte, se expressava contra os políticos da Sicília, uma das regióes menos desenvolvidas economicamente da Itália: "Que tipo de políticos estão governando esta belissima região?”(Bobba, 2019). Da mesma forma, Alexis Tsipras, líder de Syriza, na Grécia, denunciava o establishment político do seu país por implementar políticas de acordo com os ditames da 'troika' (Stavrakakis e Katsambekis, 2014).

A segunda razão para adotarmos a abordagem ideacional é a ênfase posta sobre o papel das ideias - em particular, a antítese povo-elite. Ela permite reconhecer que o populismo é um fenômeno amplo que, seja de esquerda, seja de direita, divide a sociedade. Assim, como defendido por Jan-Werner Müller, um político/ partido não pode ser enquadrado como populista apenas por criticar as elites; é crucial que manifeste uma atitude anti-pluralista (Müller, 2017). Mesmo quando o anti-pluralismo for "mitigado" por propostas mais inclusivas - como no caso dos populismos de esquerda -, está implícita em sua mensagem uma dimensão valorativa. Nesta perspectiva, portanto, o discurso não é mera retórica (Moffitt e Tormey, 2014), vista como tática discursiva (Jagers e Walgrave, 2007), mas a fala populista é sempre uma política de identidade, que também opóe um conceito artificial de povo a um "inimigo", moralizando a contraposição.

Em síntese, neste artigo definimos o populismo a partir do reconhecimento da contraposição entre povo e elite. A partir dessa definiçáo, analisamos 5.818 discursos oficiais dos presidentes da República ao longo de 35 anos para observar o fenômeno no Brasil desde a redemocratização. A próxima seção apresenta como mensuramos o conceito.

\section{Populismo e o discurso político: questóes metodológicas}

Os estudiosos têm empregado fontes diferentes para analisar o populismo, como manifestos partidários
(Rooduijn e Pauwels, 2011; Rooduijn et al., 2014), discursos dos políticos (Hawkins, 2009; 2010; Hawkins e Kaltwasser, 2017), imprensa (Rooduijn, 2014) e mídias sociais (Engesser et al., 2017). Esse artigo concentra-se na análise dos discursos presidenciais. ${ }^{7}$ Analisa oito presidentes: José Sarney, Fernando Collor, Itamar Franco, Fernando Henrique Cardoso, Luiz Inácio Lula da Silva, Dilma Rousseff, Michel Temer e Jair Bolsonaro. ${ }^{8}$ A ênfase nos discursos apresenta alguns desafios metodológicos.

Primeiramente, importa entender que há três diferentes formas de o presidente discursar oficialmente: a) discurso de posse e discurso anual perante o Congresso; b) discursos da campanha eleitoral; c) pronunciamentos oficiais feitos durante o mandato. Isoladamente, o primeiro tipo de discurso não é útil para a compreensão do fenômeno populista, já que está circunscrito a eventos específicos e se faz, portanto, pouco representativo. Ainda que os discursos de campanha eleitoral sejam fontes válidas para estudar o populismo, o uso dessa estratégia para obter votos não deve se confundir com a prática populista ao longo do mandato (ver Bonikowski e Gidron, 2016). ${ }^{9}$ Visando chegar a conclusóes abrangentes sobre o populismo enquanto prática potencial dos presidentes brasileiros, acreditamos que a melhor fonte para o estudo desse fenômeno sejam os pronunciamentos oficiais (itens a e c). Por essa razão, nos dedicamos aos discursos proferidos durante os mandatos presidenciais.

Entre 1985 e 2019, os presidentes brasileiros discursaram oficialmente 5.818 vezes. Tamanho volume de discursos indica a necessidade de se verificar o fenômeno populista ao longo de todo o período, e não apenas em determinados momentos. No trabalho seminal de Hawkins (2009), que analisa os discursos dos presidentes na América Central e na América Latina, são considerados apenas quatro discursos de Lula; no nosso banco de dados, Lula é responsável por 2.024 pronunciamentos, ou seja, 34,8\% de todo acervo.

Conforme se observa na figura 1 , o volume de discursos varia ao longo do tempo, evidenciando diferentes perfis de comunicação dos presidentes ao longo de seus mandatos.

O desafio, portanto, é evidente: qual o melhor método para se classificar tal número de discursos 
Figura 1

Número mensal de discursos oficiais por presidente da República (1985-2019)

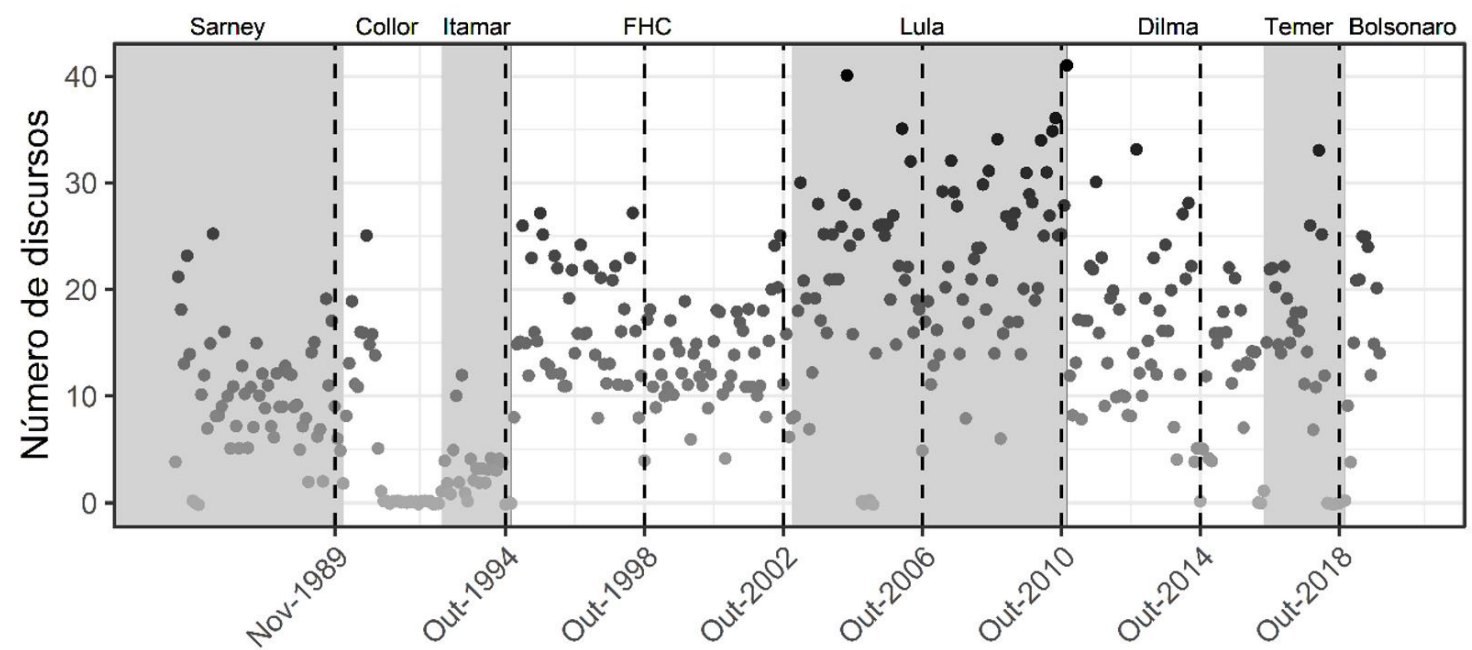

Fonte: elaboração dos autores a partir dos discursos oficiais. Banco de dados Brazilian Presidential Speeches data set (1985-2019).

como populista ou não populista? Há quem proponha uma classificação do discurso a partir de uma leitura atenta de seu conteúdo. Aqui, portanto, é necessário montar um time de codificadores que deve ser treinado para avaliar se o discurso tem caráter populista. Esta estratégia já foi explorada para o caso latinoamericano, como atestam os trabalhos de Hawkins (2009) e de Hawkins e Kaltwasser (2017). Inspirados na psicologia educacional, eles usam a holistic grading para classificar os discursos de forma escalar, entre 0 (não populista), 1 (misto) e 2 (populista). Esta metodologia é simples, mas eleva os problemas de confiabilidade da análise (Aslanidis, 2018) e a possível interferência da subjetividade dos codificadores (Pauwels, 2011), além do trabalho intensivo da mão de obra, que se torna problemático quando o número de discursos é elevado.

Com desenho metodológico misto (mixed methods design), a alternativa que adotamos se divide em quatro etapas. Na primeira, combinamos a mineração de texto (text mining) com a abordagem de dicionário (dictionary-based approach) (Grimmer e Stewart, 2013; Lucas et al., 2015; Wilkerson e Casas, 2017; Welbers et al., 2017)..$^{10}$ Dividimos todos os discursos em sentenças e, a partir de um dicionário pré-definido de palavras, selecionamos as frases com potencial de expressar conteúdo populista. Nas demais etapas, avaliamos qualitativamente se os trechos selecionados de fato caracterizam conteúdo populista, ou seja, se neles o representante expressa o antagonismo entre uma elite má, conspiradora e corrupta, que usurpa o povo bom, puro e comum. Essas quatro etapas são apresentadas a seguir.

Primeira etapa: identificação dos termos potencialmente populistas. A seleção das expressóes para o dicionário segue uma regra bastante simples: "Apenas as palavras que têm uma relação teórica clara com o conceito de populismo foram mantidas no dicionário" (Pauwels, 2011:103). Ainda que a confiabilidade seja alta, o grande problema dessa forma de operar é a validade da análise feita a partir das palavras. Quantas palavras selecionar para incorporar ao dicionário? Quais delas nos permitem qualificar com mais confiança um texto como populista? E, ainda, qual a relação entre os termos? Responder a estas perguntas não é tarefa fácil.

Nossa estratégia foi a seguinte: em uma leitura preliminar dos pronunciamentos dos presidentes, selecionamos palavras-chave que trouxessem elementos potencialmente populistas, ou seja, valorizando o povo e criticando a elite. Já que estávamos lidando com 5.818 discursos, nossa decisão foi usar como amostra pelo menos $10 \%$ dos discursos de cada presidente. Cada um dos pesquisadores leu separadamente os discursos e selecionou um conjunto de termos. A 
partir do consenso majoritário em torno dos termos, constituiu-se um dicionário-base (ver apêndice A, tabela 2). Nessa leitura identificamos 108 palavras, 27 relativas ao povo e 81 relativas à elite.

Segunda etapa: adoção de um critério de classificação do discurso. Do ponto de vista conceitual, a dúvida é se as referências ao povo e à elite deveriam estar presentes simultaneamente para a identificação de um discurso populista (Rooduijn, 2019). O termo povo aparece frequentemente nos discursos, mas nem por isso seu uso expressa conteúdo populista (Panizza, 2005). Isso porque o povo pode ser evocado em três sentidos distintos (Mudde e Kaltwasser, 2017): a) como soberano (governo do povo); b) como pessoas comuns (em virtude das condiçôes socioeconômicas e culturais); c) como nação (referindo-se à comunidade nacional). Por exemplo, Rooduijn e Pauwels (2011) admitem que a identificação do elemento relativo ao povo é quase impossível. Nem sempre nós (as pessoas) e eles (a elite) estão presentes em um discurso de forma clara e explícita, levando ao viés na codificação dos discursos populistas. A observação é ainda mais pertinente no caso brasileiro. Omitir o sujeito e o objeto é algo comum nas frases em português. A solução dos autores é, de certa forma, drástica na medida em que decidem focar apenas em termos antielite como indicador de populismo. Recentemente, Aslanidis (2018) argumenta que a intensidade da manifestação do populismo pode variar, sugerindo que não necessariamente a valorização do povo precisa estar acompanhada da demonização da elite. Quando estes dois aspectos se apresentam isoladamente, é possível falar em partial populist frame.

Em nosso entender, essa forma de abordar o populismo é metodologicamente inadequada. Como vimos anteriormente, o consenso mínimo em torno do conceito se construiu inteiro a partir da ideia de que, para que um discurso seja populista, é necessário haver contraposição explícita entre povo e elite (Hawkins e Kaltwasser, 2018). A estrutura teórica do conceito de populismo, portanto, não prevê a separação entre povo e elite. Não levar isso em conta é anular todo o esforço teórico que tem sido feito para a conceitualização do populismo. Do ponto de vista metodológico, a mera ênfase em apenas um componente do conceito pode trazer problemas de validade interna, na medida em que a mensuração não captura integralmente o fenômeno (Adcock e Collier, 2001). Portanto, se o populismo começa no ponto em que o povo se configura como uma opção antagônica à ideologia do bloco dominante (Canovan, 1981; Laclau, 2005), nossa mensuração do fenômeno deve obrigatoriamente capturar esse antagonismo.

A melhor forma de se fazer isso é deslocar a atenção para as frases, e não para os termos isolados. ${ }^{11}$ Em outras palavras, não basta encontrar povo e elite no mesmo discurso; é necessário que os dois estejam conectados de modo a configurar um conteúdo populista. As vantagens de se proceder dessa forma são significativas. Por um lado, mensuramos o populismo conforme a estrutura conceitual aceita pela literatura, aumentando a precisão na classificação do conteúdo populista. Há vantagem considerável para o entendimento do fenômeno, já que o método permite identificar em que medida os presidentes expressaram conteúdo populista, ao adotar, de forma clara, um discurso que contrapóe povo e elite. Por outro lado, o foco nas frases nos permite identificar a intensidade do uso da contraposiçấo entre povo e elite.

Terceira etapa: a identificaçâo das frases populistas. Nesta etapa separamos os discursos em frases e identificamos aquelas que possuem conotação populista. Com isso, os 5.818 discursos desdobraram-se em 481.198 frases. A tabela 1 sintetiza os resultados.

De acordo com a coluna I da tabela, Lula e Fernando Henrique Cardoso são os presidentes que mais discursaram. Juntos, eles contribuíram com aproximadamente $60 \%$ do total dos discursos oficiais. O fato de terem ambos ficado no cargo por oito anos justifica o resultado. Contudo, considerando os dias de mandato, Lula e Bolsonaro se destacam como os que mais discursaram, com médias respectivas de 0,69 e 0,56 discursos por dia. ${ }^{12}$ Conforme a coluna III, Lula, Dilma e Fernando Henrique fizeram os discursos mais longos, com uma média aproximada de 2 mil palavras.

Em seguida, com base na lista do dicionário-base elaborado na primeira etapa, identificamos quais frases que possuíam um conteúdo potencialmente populista. Se, como vimos, um populista é aquele que, em seus discursos, expressa o antagonismo entre povo e elite, uma frase é considerada: ${ }^{13}$ 


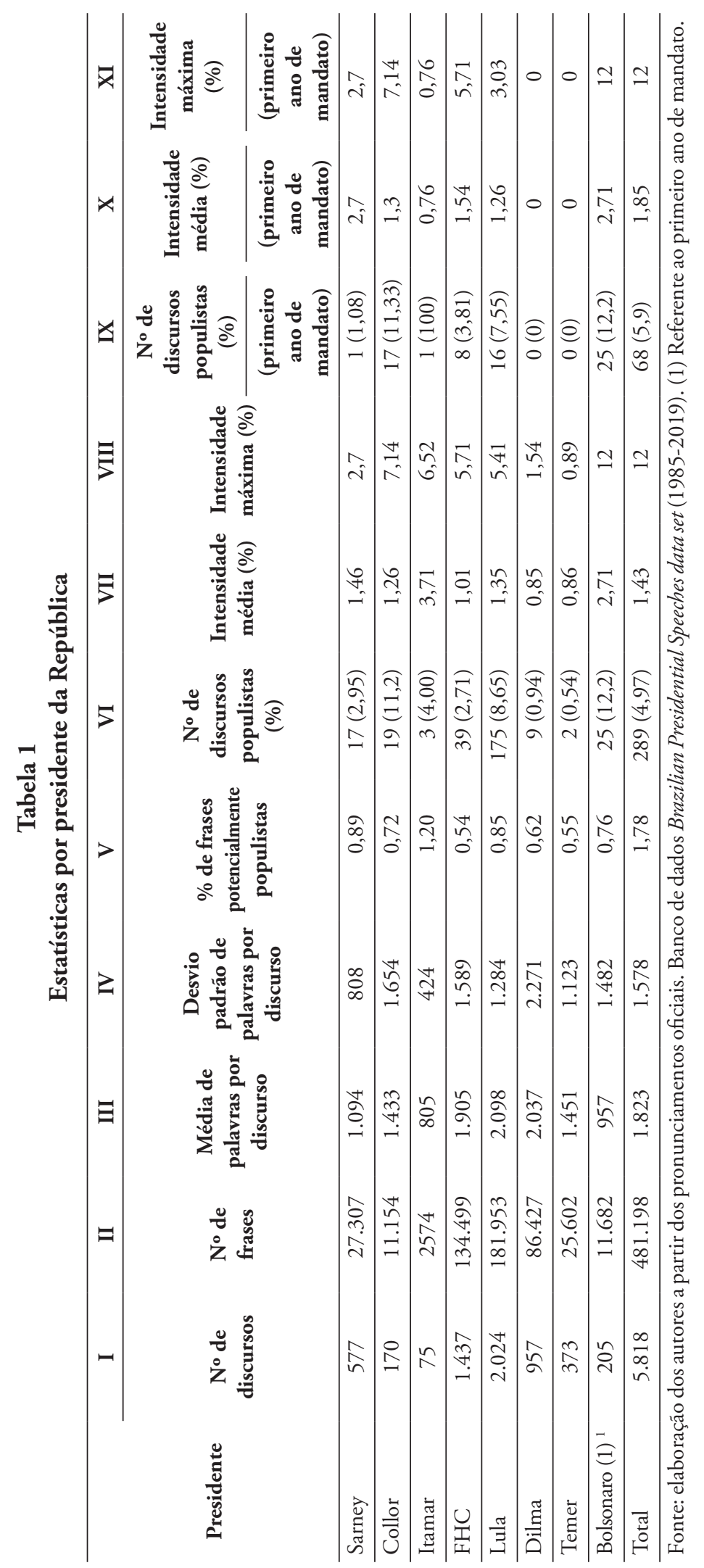


- Tipo 1) Populista, quando faz referência ao povo (valorizando-o) e à elite (criticando-a) ao mesmo tempo.

- Tipo 2) Não populista, quando é favorável ao povo, mas não faz referência à elite.

- Tipo 3) Não populista, quando é contra a elite, mas não faz referência ao povo.

- Tipo 4) Não populista, quando não se faz nenhuma referência positiva em relação ao povo e nenhuma referência negativa em relação à elite; ou quando nenhuma das palavras-chave estão presentes.

A coluna $V$ da tabela apresenta os percentuais de potenciais frases do tipo 1 . Seguindo esse critério, cerca de $1,78 \%$ das frases são potencialmente populistas (8.585 frases). Em geral, essa porcentagem varia por presidente, sendo que Fernando Henrique é aquele com a menor proporção de frases potencialmente populistas $(0,54 \%)$ e Itamar Franco possui a maior (1,20\%). Dizemos potencialmente populistas, pois é possível que haja entre elas frases contendo termos referentes a elite e povo, mas que não ressaltem o antagonismo entre estes dois grupos.

O foco nas frases não elimina o problema do uso de uma das palavras-chave sem conotação populista. O então presidente Itamar Franco, por exemplo, por ocasião da devolução do terreno da sede da União Nacional dos Estudantes (UNE), no Rio de Janeiro, em 18 de maio de 1994, proferiu as seguintes palavras: "Convém lembrar que a UNE e as entidades estudantis regionais que a formavam, com a democracia que praticavam e defendiam, asseguravam a ascensão de jovens de origem modesta às elites políticas nacionais". Está claro que o presidente não fazia um ataque às elites detentoras do poder. $\mathrm{O}$ termo elites foi utilizado apenas para ressaltar a forma como a classe estudantil ascendera politicamente a um papel relevante no cenário nacional.

Assim, nesta etapa, diferenciamos qualitativamente, entre as 8.585 frases potencialmente populistas, quais o são e quais não o são. Para que o resultado da classificação manual tivesse alta confiabilidade, as sentenças potencialmente populistas foram classificadas de forma independente por cada um dos três pesquisadores. Foram consideradas populistas automaticamente as sentenças cujo conteúdo foi classificado assim por todos. Quando uma sentença foi classificada como populista por apenas dois autores, optou-se por debater seu conteúdo para posterior classificação. Por fim, as sentenças cujo conteúdo foi classificado como populista por apenas um, ou por nenhum dos autores, não foram consideradas como tal. Este procedimento resultou em 407 frases populistas.

Quarta etapa: identificaçâo dos discursos populistas. Um discurso foi classificado como populista quando seu conteúdo possuía ao menos uma frase populista. As colunas VI, VII e VIII da tabela apresentam os resultados. No apêndice B apresentamos exemplos de frases classificadas como populistas ou não populistas. Nas próximas seções nos dedicamos aos principais resultados e respondemos à questão de pesquisa: quão populistas são os presidentes brasileiros?

\section{Populismo e o discurso político: quão populistas são os presidentes brasileiros?}

Classificar os discursos com conteúdo populista nos permite identificar em que medida os presidentes utilizaram esse recurso, ou seja, em maior ou menor proporção. Conforme a coluna VI da tabela 1, ordenando os presidentes do menos populista para o mais populista (em termos da porcentagem de discursos populistas), temos: Michel Temer (0,54\%); Dilma Rousseff (0,94\%); Fernando Henrique Cardoso (2,71\%); José Sarney (2,95\%); Itamar Franco (4\%); Lula (8,65\%); Fernando Collor (11,2\%) e Jair Bolsonaro (12,2\%). Observa-se que três presidentes se sobressaem: Lula, Collor e Bolsonaro. Juntos, os três respondem por $75,8 \%$ de todos os discursos populistas proferidos durante a Nova República. Notase, também, que Jair Bolsonaro é o mais populista de todos. Com apenas um ano de governo, apresentou quase o mesmo número de discursos dessa natureza que Fernando Henrique ao longo de seus oito anos de mandato. A figura 2 a seguir ilustra a distribuição mensal dos discursos populistas.

Uma medida interessante de se avaliar é a intensidade dos discursos populistas. Entendemos por intensidade a porcentagem de frases populistas em relação ao total de frases do discurso. Assim, se um discurso possui 50 frases e 20 exaltam o povo e criticam a elite, a intensidade é de $40 \%$. Vemos, 
Figura 2

Número mensal de discursos populistas por presidente da República (1985-2019)

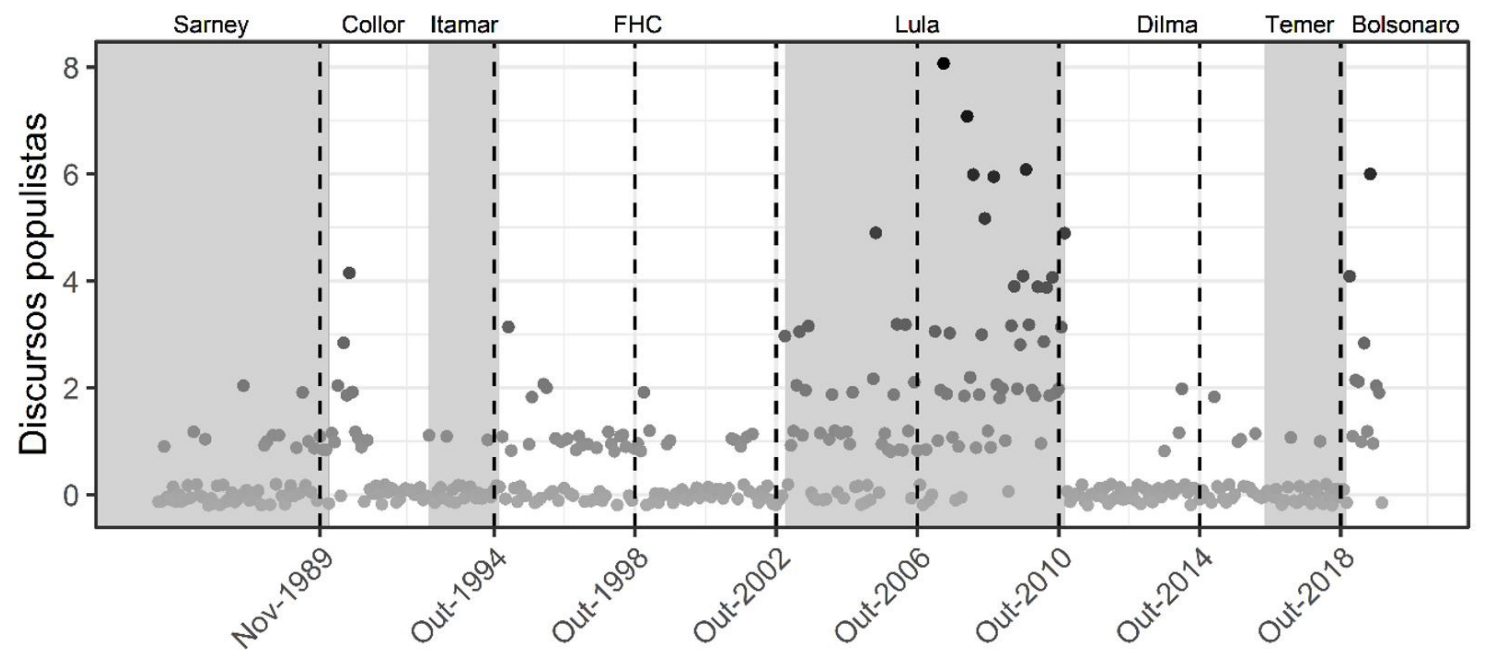

Fonte: elaboração dos autores a partir dos discursos oficiais. Banco de dados Brazilian Presidential Speeches data set (1985-2019)

pelas colunas VII e VIII da tabela 1 que, em média, os discursos classificados como populistas apresentam uma intensidade média de 1,43\%. No entanto, há uma variação entre os presidentes. Dois presidentes se sobressaem: Itamar Franco e Jair Bolsonaro, com médias de $3,71 \%$ e $2,71 \%$, respectivamente. Pode-se concluir que Itamar não deveria ser considerado um presidente populista, pois concentrou o antagonismo entre povo e elite em apenas três discursos. ${ }^{14} \mathrm{O}$ que faz um presidente ser populista não é a eventualidade de uma fala, mas sua durabilidade. Bolsonaro, por sua vez, além de apresentar muitos discursos populistas, tende a fazer mais pronunciamentos intensos. $\mathrm{O}$ discurso mais populista de nosso conjunto de dados foi proferido por ele, e tinha $12 \%$ de frases populistas. Não por acaso, esse é o discurso que o presidente brasileiro pronunciou no dia 28 de fevereiro de 2019, após se reunir com o autoproclamado presidente da Venezuela, Juan Guaidó. Seu discurso de posse não se distancia muito deste, ficando com uma intensidade de 8,5\%.

Importa lembrar que a pesquisa considerou apenas o primeiro ano de exercício da presidência de Bolsonaro. Assim, para fins comparativos, as colunas IX, X e XI da tabela 1 mostram os resultados da análise dos discursos do primeiro ano de todos os presidentes. Como é possível constatar, os resultados anteriores se mantêm. Collor, Lula e Bolsonaro continuam sendo os presidentes mais populistas do período democrático atual. A exceção a esse padrão é Itamar Franco, que apresentou $100 \%$ de discursos populistas em seu primeiro ano de governo. No entanto, como o seu mandato começou em 29 de dezembro de 1992, ele proferiu apenas um discurso no período - de resto, com conteúdo populista.

\section{Collor, Lula e Bolsonaro: que populismo é esse?}

Nesta seção aprofundaremos as diferenças entre os três presidentes brasileiros mais populistas do período da pesquisa, levando em conta o conteúdo dos discursos analisados.

Pode-se dizer que o populismo de Collor se expressa na contraposição entre o povo e o Estado ou as elites. Em seus discursos, aparece claramente a oposição povo às vezes identificado aos pobres e aos trabalhadores - versus Estado corrupto, associado à classe política, ao governo, ao funcionalismo público; mas também contra as elites econômicas (sobretudo os empresários) e as grandes corporaçôes (os sindicatos). Estas últimas são apresentadas como aliadas do Estado, vivendo à sombra dele, explorando os trabalhadores. Assim, conforme já defendido por outros, Collor "contribuiu para danificar 
o quadro institucional nacional-desenvolvimentista e redirecionar a sociedade brasileira em um sentido anti-estatal e internacionalizante" (Sallum, 2003:42; Weyland, 2003).

$\mathrm{O}$ aspecto mais marcante que emerge no discurso de Lula é a contraposição entre rico e pobre. A ênfase no reconhecimento de que grande parte da população não goza de condiçóes mínimas de bem-estar, em função de uma elite rica que a usurpa, é expressão de um populismo inclusivo típico da América Latina e diferente do europeu (Mudde e Kaltwasser, 2013). De acordo com esta visão, o político valoriza o papel do Estado como agente promotor da incorporação dos excluídos - que, em Lula, são frequentemente identificados à categoria ampla e homogênea dos pobres. Pode-se dizer que isso reflete a visão de mundo de Lula que, nos termos de John French, se resumia à disputa para "ganhar voz em uma sociedade caracterizada por hierarquias subalternizantes e governo despótico, tanto politicamente quanto nas fábricas" (French, 2009:366).

A identificação de um discurso populista em Lula é importante tendo em vista o debate sobre o populismo na América Latina. Para muitos autores, Lula não é um líder populista em comparação com os demais presidentes latino-americanos. Pelo menos era o que vários estudiosos defendiam (Bethell, 2018; Hunter e Power, 2007; Levitsky e Loxton, 2013). Ao exemplificar o ponto, Juan Grigera (2017) toma como exemplo a Carta ao povo brasileiro, em que Lula se compromete com a ordem neoliberal. A força política de Lula estaria na sua capacidade de acomodar vários atores, mitigando o conflito social.

Já para outros há traços modestos de populismo nos discursos de Lula (Hawkins, 2009). Na comparação com outros líderes políticos mundiais - Hugo Chávez, Evo Morales e Michelle Bachelet, na América Latina; Silvio Berlusconi, Viktor Yushchenko e Vladimir Putin, na Europa; e Thaksin Shinawatra e Gloria Macapagal Arroyo na Ásia -, o grau de populismo de Lula foi classificado como baixo, situando-o "na extremidade inferior da escala populista" (Hawkins e Selway, 2017:387). No entanto, quando comparado com seus pares brasileiros, Lula se destaca como um líder político populista.
As discordâncias registradas entre os autores resultam das diferentes abordagens adotadas. Em muitos casos, quem não reconhece o caráter populista de Lula não enfatiza seu discurso, mas sua atuação política. Nesta perspectiva, destaca-se sua responsabilidade fiscal e econômica, além da defesa das instituições democráticas e do diálogo com as instituiçóes representativas (Bethell, 2018). Entretanto, a associaçáo entre populismo e performance econômica - e a ênfase no respeito pelas instituiçóes democráticas - acaba por reduzir o populismo a um fenômeno intrinsecamente dependente dos efeitos produzidos. Como já afirmamos, nossa abordagem, assim como a de Hawkins (2009), enfatiza, como elemento central do discurso populista, a construção de uma política de identidade pela contraposição moralizante entre um conceito artificial de pessoas (ou povo) e algo que é seu inimigo. Ainda que Lula adote uma política conciliadora, não há como não reconhecer que frequentemente ele flerta com a ideia de que a sociedade brasileira deve ser interpretada a partir do antagonismo entre dois grupos: de um lado, os pobres e, de outro, os ricos.

Após o monopólio da disputa presidencial entre PT e PSDB, Bolsonaro se aproveita de uma crise política e econômica para ascender ao poder (Hunter e Power, 2019). O populismo de Bolsonaro é menos abstrato do que o de Lula: povo e elite têm semblantes facilmente identificáveis. De um lado, quando Bolsonaro fala em povo, ele distingue claramente, entre os brasileiros, os compatriotas, que defendem os valores da família tradicional. Por outro lado, seu anti-pluralismo é marcante. Não se questiona apenas a atuação das elites políticas ou do Estado em geral, como fez Collor, mas também a ideologia de gênero defendida pela esquerda, que valoriza alguns grupos em detrimento da família tradicional. Nesse sentido, o populismo de Bolsonaro é excludente (Mudde e Kaltwasser, 2013), isto é, não aceita a inclusão de alguns grupos específicos na noção de povo. Aqui, cabe uma reflexão que estudos futuros deveriam aprofundar: Bolsonaro é coerente com um discurso de tipo nacionalista?

A relação entre populismo e nacionalismo é um tema de pesquisa recente. $\mathrm{O}$ conceito-chave do nacionalismo é a nação, isto é, uma comunidade limitada no território e no tempo, em oposição a 
outras (De Cleen, 2017). Assim, em seu discurso, os nacionalistas valorizam a própria comunidade, concebida política e culturalmente como nação e definida por categorias étnicas especificas (Caiani e Kroll, 2017). Ou seja, nem sempre o populismo constitui o único aspecto ideológico envolvido: "A pesquisa contemporânea precisa reconhecer a prioridade de elementos nacionalistas e xenófobos, anti-imigração e, de forma geral, exclusivistas no discurso desses partidos" (Stavrakakis et al., 2017:13-14).

Tamaki e Fuks (2020), no que é um dos primeiros estudos a tratar de mensurar o grau de populismo do presidente brasileiro atual, reconhecem elementos patrióticos e nacionalistas em seus discursos de campanha - ainda que centrados nas ideias de nação e Estado. Entretanto, quando se analisa o discurso de Bolsonaro durante seu mandato, como fizemos neste artigo, traços claramente patrióticos e nacionalistas são minoritários.

A questão é que o nacionalismo é uma categoria que pode ser explorada também em relação à própria comunidade. Segundo Charles e Hintjens (1998), a imagem de uma nação é sexualmente construída e defendida, como quando se acusa os homens gays, por exemplo, de não possuir virtudes tipicamente masculinas como "força de vontade, honra, coragem" (Nagel, 1998). Na Letônia, por exemplo, os partidos têm apresentado a homossexualidade como expressão de um comportamento anti-nacionalista (Mole, 2011). A luta contra a ideologia de gênero, por exemplo, é um elemento central do programa e dos discursos dos políticos da Alternative für Deutschland (afd) na Alemanha (Keil, 2020). De Lange e Mugge (2015), ao estudar os manifestos dos partidos populistas na Holanda e em Flandres, encontram evidências de que alguns incorporam as questóes de gênero, afetando inclusive outras temáticas; assim, "a política anti-imigração não só se concentrou nos imigrantes muçulmanos, mas também se tornou explicitamente ligada a questôes de gênero" (De Lange e Mugge, 2015:63).

A ideia de comunidade é, portanto, ampla e continuamente remodelada. Visto sob este ângulo, o nacionalismo de Jair Bolsonaro não é essencialmente identitário, isto é, construído sobre bases raciais ou étnicas ou nativistas, como acontece na Europa. É construído pelo prisma da cristandade, graças às influências pentecostais.

É prematuro chegar a alguma conclusão sobre o que poderíamos chamar de nacional-populismo de Bolsonaro. Contudo, acreditamos ser útil afirmar que os dois fenômenos deveriam ser compreendidos sob o prisma da articulação dos dois termos, a partir de uma clara distinção entre eles (De Cleen e Stavrakakis, 2017).

\section{Discussáo: o populismo e a democracia no Brasil}

Há quem reconheça o populismo como um elemento incompatível com a democracia, sobretudo porque se associa à defesa de atitudes anti-pluralistas (Müller, 2011; Pasquino, 2008; Urbinati, 2019). Outros acreditam que o populismo é útil a uma democracia liberal, ao criar novas identidades coletivas que melhoram a participação política entre cidadãos apáticos ou descrentes dos partidos tradicionais (Mouffe, 2013). Este aspecto corretivo do populismo seria útil apenas nas democracias consolidadas, por dar voz às pessoas não representadas sem constituir ameaça real às instituiçōes representativas (Mudde e Kaltwasser, 2012). Diante dessas duas correntes, o que dizer a respeito do Brasil? Se o caráter democrático de Lula nunca foi questionado, a eleição de Bolsonaro é vista como um risco para a democracia (Smith, 2020).

O tema é amplo e complexo. Sem sermos exaustivos, discutiremos a possível ameaça à democracia a partir de dois aspectos que nos parecem fundamentais para pensar o populismo brasileiro. O primeiro é o peso atribuído à dimensão carismática, sobretudo pensada como parte de uma açáo que mobiliza as pessoas e estimula a identificaçáo com o líder (Weyland, 2001). ${ }^{15}$ O debate sobre a importância (ou não) do carisma do líder está em aberto justamente porque o termo é vago e empregado de forma ampla (Mudde, 2007). Aqui, adotamos a definição de Takis Pappas - que, inspirando-se em Weber, define o carisma político como um "tipo distinto de liderança legitima que é pessoal e visa a transformação radical de uma ordem institucional estabelecida" (Pappas, 2016:3).

Nesta definição, o conceito tem dois atributos: personalismo e radicalismo. Ambos devem estar 
presentes para que um político seja reconhecidamente carismático. O personalismo diz respeito a a) uma liderança indiscutível dentro do partido e b) uma relação direta com os seguidores, com um sentido quase que missionário. $\mathrm{O}$ radicalismo, por sua vez, se caracteriza pela a) deslegitimação sistemática do status quo visando b) criar uma nova ordem jurídica e institucional. Pensados nestes termos, Chaves (Venezuela), Correa (Equador), Morales (Bolívia), Ortega (Nicarágua) seriam exemplos de líderes populistas carismáticos na América Latina (Balderacchi, 2018). Aplicando a definição que ele mesmo elabora a 45 líderes europeus, Pappas conclui que apenas cinco podem ser considerados carismáticos: Le Pen, Orban, Berlusconi, Haider e Papandreou (Pappas, 2016). Outros autores mostram que a ideia de um líder forte, que controla cada aspecto da vida partidária, não passa de um mito (Heinisch e Mazzoleni, 2016). O triunfo em várias eleiçóes sucessivas dependeria de uma organização complexa, capaz de coordenar as instâncias locais e nacionais e de viabilizar a participação dos ativistas locais. Sem uma organização sólida, os partidos populistas não se sustentam no longo prazo (Gherghina e Soare, 2019), mesmo que haja um líder carismático (Van der Brug e Mughan, 2007).

Essa discussão é útil para refletir sobre a natureza do populismo no Brasil. De acordo com a definição de Pappas, nenhum dos três presidentes brasileiros considerados populistas - Collor, Lula e Bolsonaro - é plenamente carismático. Isso significa que a possível ameaça à democracia náo deriva de carisma. Collor, apesar da fala "antissistema", sugerindo grandes mudanças do status quo, foi um líder populista sem partido político. O partido que o elegeu em 1989, o Partido da Reconstruçáo Nacional (PRN), teve vida efêmera e já estava sem apoiadores nas eleições municipais de 1992. Como bem observou Paul Cammack, o político alagoano buscou perseguir seus objetivos neoliberais sem se apoiar em uma instituição partidária, "falindo espetacularmente" (Cammack, 2000:159; ver também Weyland, 2001).

Pode-se dizer que o quadro não é tão diferente quando se trata de Bolsonaro. Apesar do discurso que defende uma "nova política", da constante deslegitimação de adversários e das instituições e da capacidade de mobilizar pessoas, ${ }^{16}$ Bolsonaro foi incapaz de gerenciar as relaçóes com parte dos membros do Partido Social Liberal e, após um ano de governo, decidiu abandonar a sigla da qual dependeu para se eleger, embarcando, sem muito entusiasmo, na aventura de criar seu próprio partido.

A liderança de Lula é reconhecida nacional e internacionalmente, assim como a ideia de que o PT é um dos poucos partidos no Brasil com bases organizacionais sólidas, a nível nacional (Ribeiro, 2014). Aqui, cabe uma observação: apesar dos inúmeros estudos já produzidos, o partido de Lula nunca foi analisado dentro da ótica do populismo. Seria o PT um partido populista? À espera de estudos que o façam, podemos apresentar a seguinte hipótese de pesquisa: o populismo inclusivo de Lula condicionou também a forma de o partido apresentar e defender seus ideais. Dois exemplos esclarecem esse ponto. Em uma cartilha organizada pelo PT em 2019, objetivando colocar na mesa propostas concretas para tirar o Brasil da crise, leem-se frases de cunho populista, como: "Nada de entregar as riquezas aos estrangeiros. O que é do Brasil é do povo brasileiro" ou "O imposto no Brasil pesa mais no bolso do pobre do que do rico [...]. Já passou da hora de acabar com essa injustiça".

No plano de governo apresentado em 2018 pelo então candidato à presidência Fernando Haddad, cuja companheira de chapa era Manuela d'Ávila, do PC do B, podem também ser encontradas frases de clara conotação populista, como:

A cada dia que passa, vai aparecendo o principal objetivo da coalizão golpista: inverter as políticas que valorizaram, nos governos Lula e Dilma, o Trabalho diante do Capital, a Nação diante do Império, as maiorias e minorias oprimidas e discriminadas diante de uma elite misógina e racista, autoritária e excludente.

O presidente Lula enfrentou o preconceito das elites contra os pobres e criou o Programa Bolsa Família.

O governo ilegítimo introduziu medidas e reformas que colocam os custos da crise sobre os mais pobres e que liberam a exploraçấo desenfreada da nossa vasta riqueza natural, inclusive vendendo nossas terras e ativos ambientais aos estrangeiros. 
A questão é que, mesmo admitindo a centralidade de Lula no controle do partido - ou, ainda, sua personalidade e carisma pessoal -, Lula não é um líder radical. Em síntese, se o populismo é uma ameaça à democracia, há uma certeza que atenua sua periculosidade: a ausência do líder carismático.

O caso europeu nos leva a refletir sobre um segundo aspecto da relação entre populismo e democracia. Trata-se do papel exercido pelos partidos populistas após as eleiçôes. Como bem enfatizou Nadia Urbinati, precisamos estudar como tais partidos atuam nos parlamentos e, sobretudo, no governo (Urbinati, 2019). Concretamente, isso significa, por um lado, estudar a formação de governos (Mudde, 2017b). $\mathrm{Na}$ Europa, o sucesso dos partidos populistas não é apenas eleitoral; ele é visível na ocupação de cargos de governo. O exemplo mais extremo talvez seja o caso da Hungria, onde o partido de Viktor Orbán, no poder desde 2010, governa sozinho. A Itália é o caso mais sintomático da crise dos partidos tradicionais, ao formar, em 2018, um governo com dois partidos populistas, a Liga Norte e o Movimento Cinco Estrelas. Quando os partidos populistas não obtêm um número de cadeiras suficiente para compor um governo unipartidário, formam coalizões com partidos não populistas.

Por outro lado, é de importância fundamental compreender também a atuação de partidos/políticos durante o mandado - por exemplo, na apresentaçáo de projetos de lei. Quando no poder, os partidos populistas perseguem políticas que ameaçam a estabilidade da democracia, aprovando, por exemplo, leis contra o judiciário ou minorias, ou que ameacem a liberdade de expressão (Albertazzi e Mueller, 2013).

No Brasil, por sua vez, nunca o partido de um presidente populista foi preponderante no Congresso Nacional. O PRN de Collor conquistou cerca de 8\% das cadeiras na eleição de 1990. Mais bem-sucedido, o PT conseguiu cerca de $17 \%$ das cadeiras na Câmara e 16\% no Senado em 2002 - e em números menores nas eleiçóes sucessivas. O PSL de Bolsonaro conquistou cerca de $10 \%$ das cadeiras na Câmara e 5\% no Senado em 2018.

A constatação não é de pouca monta: o fato é que, no Brasil, os presidentes não têm conquistado uma base de representação forte no parlamento. Como sabemos, cabe aos presidentes brasileiros, uma vez eleitos, construir uma maioria sólida dentro do Congresso para poder governar. O resultado é conhecido: o presidencialismo de coalizão (Figueiredo e Limongi, 1999). Se Collor abdicou voluntariamente da tentativa de construir uma maioria parlamentar estável (Sallum e Casaróes, 2011) e Lula perseguiu uma estratégia de cooperação com o Congresso Nacional, construindo amplas alianças com os demais partidos, Bolsonaro, em seu primeiro ano de governo, nem sequer tentou negociar uma coalizão, resultando em conflito e tensōes constantes.

A questão pode ser resumida nestes termos: paradoxalmente, a tão criticada fragmentação partidária do Congresso Nacional constitui um freio ao possível viés populista da presidência. Sabemos que líderes populistas tendem a manifestar certo ativismo constitucional, visando concentrar poderes e erodir as instituiçôes democráticas liberais (Huq e Ginsburg, 2018). Podemos ter dúvidas quanto à eficiência do presidencialismo de coalizão, mas náo quanto à sua capacidade de mitigar a ação dos presidentes que, para implementar sua agenda, devem necessariamente cooperar com os partidos no Congresso.

À guisa de conclusão, podemos dizer que o populismo é um aspecto saliente da democracia brasileira, na qual o presidencialismo de coalizão atua como fator de enfraquecimento da autonomia do próprio presidente. Em síntese, se há motivos de alarme quando se pensa nos efeitos perversos do populismo para a democracia brasileira, estes dependem muito menos do carisma pessoal e das instituiçóes representativas, e bem mais da capacidade do presidente populista de buscar proteção fora delas, contornando-as.

\section{Agradecimentos}

A pesquisa conduzida neste artigo teve o suporte financeiro da Fapesp (projeto 18/23060-2).

\section{Notas}

1 A reflexão de Weffort tem como ponto de partida a crítica à obra de Gino Germani (1971) que, refletindo sobre o caso argentino, explicava o populismo em função do processo de modernização observado na transição 
de uma sociedade tradicional para outra, moderna, representando uma etapa do desenvolvimento latinoamericano. Para Germani, o populismo era uma aberraçáo e uma anomalia, tendo em vista que na Argentina as classes operárias apoiavam Perón, em vez dos partidos de classe. Ainda que Weffort se sirva da imagem de uma sociedade em transição para tratar do caso brasileiro, o autor foi influenciado por uma abordagem marxista. Nesta perspectiva, o populismo é o produto da crise de hegemonia das velhas elites agrárias da Primeira República, mas sem que uma hegemonia burguesa a substituísse. Para mais detalhes sobre a obra de Weffort ver ainda Mussi e Kaysel (2020).

2 Não pretendemos oferecer uma revisão exaustiva do populismo das décadas de 1950 e 1960. Para aprofundar o tema, remetemos à ainda atual resenha de Ângela de Castro Gomes (1996).

3 As citaçóes extraídas de textos em outras línguas que aparecem no artigo foram traduzidas pelos autores.

4 Aqui, nos referimos, sobretudo, às obras Politics and Ideology in Marxist Theory (Laclau, 1977) e On Populist Reason (Laclau, 2005). Em sua primeira obra, ainda influenciado pelo marxismo, Laclau reconhecia a essência do populismo no antagonismo entre elementos populares e uma ideologia dominante (da oligarquia fundiária na América Latina). Já no segundo livro, fruto de longa reflexáo em chave pós-marxista, que se inicia nos anos 1980, Laclau abandona a ideia de um povo já constituído e passa a tratar o populismo como o processo pelo qual uma plebe - uma massa indeterminada e não representada de pessoas - se constitui como um populus.

5 Para uma reconstrução das vertentes que estudam o populismo e das abordagens empíricas usadas, ver o recente Handbook of populism (2017). Para uma discussão em português, ainda que circunscrita à área da comunicação política, ver Cavassana e Cervi (2018).

6 A abordagem ideacional se distancia daquela de Laclau em vários pontos; mas o que mais interessa ressaltar, para o tema discutido neste texto, é a percepção de que o significado de povo náo é inteiramente vazio. $\mathrm{Na}$ abordagem ideacional, o povo é visto como sujeito homogêneo e puro, algo que remete a uma concepção idealizada de comunidade. Assim, nesta perspectiva, populismo é definido de forma mais precisa como algo em que "a oposição principal é moral, e é empiricamente orientada, positivista e destinada a desenvolver teorias de médio alcance" (Mudde, 2017b:40).

7 Obviamente uma compreensão conclusiva do populismo no Brasil deve passar pelo estudo de outras fontes e materiais, como por exemplo os discursos de plenário, os programas partidários e, no caso de Bolsonaro, as lives. O reconhecimento da importância de uma abordagem multidimensional das fontes não é apenas questáo de preciosismo empírico, mas indispensável para, por exemplo, validar ou não os resultados encontrados aqui.

8 Os discursos dos ex-presidentes brasileiros estáo disponíveis em http://www.biblioteca.presidencia.gov.br/presidencia/ ex-presidentes (acessado em 27 fev. 2021). No caso de Jair Bolsonaro, consideramos apenas os pronunciamentos do primeiro ano no cargo, ou seja, até dia $31 \mathrm{dez} .2019$. Todos os discursos foram obtidos através da raspagem do conteúdo publicado (webscraping).

9 Considere-se, também, que a linha que separa discursos oficiais e de campanha é tênue. Como os presidentes se aproveitam de eventos oficiais para discursar em épocas eleitorais, sobretudo quando buscam sua reeleição, a distinçấo entre as duas categorias discursivas não é tấo nítida.

10 Os estudos centrados na análise de conteúdo não são desconhecidos na ciência política brasileira. A título de exemplo, ver estudo conduzido sobre os manifestos partidários para a identificação da posiçâo ideológica dos partidos (Tarouco e Madeira, 2013), sobre programas de governo de candidatos ao executivo (Salles, 2019), sobre os discursos parlamentares (Moreira, 2019; Moreira, 2020; Izumi, 2017; Miguel e Feitosa, 2009). Para mais detalhes sobre as metodologias, ver Izumi e Moreira (2018).

11 As frases foram definidas por meio de pontuação. A quebra do texto foi feita a partir da ocorrência de pontos finais, pontos de interrogação ou de exclamação. A exceção a esta regra é quando o ponto final foi utilizado em abreviaçóes, como em "Dr.", "Dra.", "Sr." ou "Sra".

12 Sarney $(577 / 1789=0,32)$; Collor $(170 / 980=0,17)$; Itamar $(75 / 733=0,10)$; FHC $(1437 / 2922=0,49)$; Lula $(2024 / 2922=0,69)$; Dilma $(957 / 2069=0,46)$; Temer $(373 / 853=0,44)$; Bolsonaro $(205 / 364=0,56)$.

$13 \mathrm{O}$ apêndice $\mathrm{B}$ apresenta alguns exemplos de frases dos tipos 1 a 3 .

14 No primeiro pronunciamento, de 14 jun. 1993, Itamar Franco acusa as elites empresariais de serem "alienadas", sem compromisso com o povo. No segundo, de $30 \mathrm{dez}$. 1992, afirma que há uma crise do Estado, com a perda de valores tradicionais de referência. No terceiro, de 11 ago. 1994, as elites são chamadas de "insensíveis" e acusadas de contribuir para acentuar as diferenças sociais.

15 Nas abordagens sobre populismo, a liderança política exerce um importante papel na construção da identidade coletiva já que, como diz Kirk Hawkins (e outros) retomando Laclau, "O líder carismático é um componente essencial desse processo porque ele ou ela fornece um referente físico, um 'significante vazio', no qual diferentes cidadãos podem conectar seus interesses individuais" (Hawkins et al., 2017: 270). 
16 São ainda incipientes os estudos sobre o bolsonarismo. Para Lucio Rennó (2020), os apoiadores de Bolsonaro são conservadores em relação a questôes sociais e morais, e estão menos satisfeitos com a democracia do que seguidores de outros políticos. Para De Almeida e Guarnieri (2020), o eleitor de Bolsonaro é principalmente branco, jovem, de renda média a alta, neopentecostal e residente nas regióes Sul ou Centro-Oeste, mas não apresenta grandes diferenças quanto à insatisfação com a democracia, na comparação com quem escolheu outros candidatos.

\section{BIBLIOGRAFIA}

ACEMOGLU, Daron; EGOROV, Georgy \& SONIN, Konstantin. (2013). "A political theory of populism". The Quarterly Journal of Economics, 128, 2:771-805.

ADCOCK, Robert \& COLLIER, David. (2001), "Measurement validity: A shared standard for qualitative and quantitative research". American Political Science Review, 95, 3:529-546.

ALBERTAZZI, Daniele \& MUELLER, Sean. (2013). "Populism and liberal democracy: Populists in government in Austria, Italy, Poland and Switzerland". Government and Opposition, 48, 3:343-371.

ASLANIDIS, Paris. (2018), “Measuring populist discourse with semantic text analysis: an application on grassroots populist mobilization”. Quality \& Quantity, 52, 3:1241-1263.

BALDERACCHI, Claudio. (2018), "Political leadership and the construction of competitive authoritarian regimes in Latin America: implications and prospects for democracy". Democratization, 25, 3:504-523.

BETHELL, Leslie. (2018), "Populism in Brazil", in BETHELL, Leslie, Brazil: Essays on History and Politics, University of London, Institute of Latin American Studies.

BOBBA, Giuliano. (2019), "Social media populism: features and 'likeability' of Lega Nord communication on Facebook”. European Political Science, 18, 1:11-23.

BONIKOWSKI, Bart \& GIDRON, Noam. (2016), "The populist style in American politics:
Presidential campaign discourse, 1952-1996". Social Forces, 94, 4:1593-1621.

CAIANI, Manuela \& Patricia KRÖLL. (2017), "Nationalism and populism in radical right discourses in Italy and Germany". Javnost-The Public, 24, 4:336-354.

CAMMACK, Paul. (2000), “The resurgence of populism in Latin America". Bulletin of Latin American Research, 19, 2:149-161.

CANOVAN, Margaret. (1981), Populism. Boston: Houghton Mifflin Harcourt.

CAVASSANA, Fernanda \& CERVI, Emerson U. (2018), "Mais populismo, menos representatividade: monitoramento e lógica populista da comunicação política em redes sociais online”. Revista Estudos Politicos, 9, 1:86-103.

CODATO, Adriano; BERLATTO, Fábia \& BOLOGNESI, Bruno. (2018), “Tipologia dos políticos de direita no Brasil: uma classificação empírica”. Análise Social, 229, 4:870-897.

CHARLES, Nickie \& HINTJENS, Helen. (1998), "Gender, Ethnicity and Cultural Identity: Women's 'Places', in CHARLES, Nickie \& HINTJENS, Helen (orgs.), Gender, Ethnicity and Political Ideologies, Londres/Nova York, Routledge, pp. 1-26.

DAGNINO, Evelina (org.). (1994), Anos 90: política e sociedade no Brasil. São Paulo, Brasiliense.

DE ALMEIDA, Maria Herminia Taraves \& GUARNIERI, Fernando. (2020), "The unlikely presidente". Revista Euro-latinoamericana de Análisis Social y Político, 1, 1:139-159.

DE CLEEN, Benjamin. (2017), "Populism and nationalism", in KALTWASSER, Cristóbal Rovira et al., The Oxford Handbook of Populism, Oxford University Press, pp. 342-362.

DE CLEEN, Benjamin, \& STAVRAKAKIS, Yannis. (2017). "Distinctions and articulations: A discourse theoretical framework for the study of populism and nationalism". Javnost-The Public, 24, 4:301-319.

DE LANGE, Sarah L. \& MÜGGE, Liza M. (2015), "Gender and right-wing populism in the Low Countries: ideological variations across parties and time". Patterns of Prejudice, 49, 1-2:61-80. 
DE LA TORRE, Carlos. (2003), "Masas, pueblo y democracia: un balance crítico de los debates sobre el nuevo populismo". Revista de Ciência Política, 23, 1:55-66.

DE LA TORRE, Carlos. (2009), "Populismo radical y democracia en los Andes". Journal of Democracy, 1, 1:24-37.

DORNBUSCH, Rudiger \& EDWARDS, Sebastian. (1991), "The macroeconomics of populism", in DORNBUSCH, Rudiger, \& EDWARDS, Sebastian (orgs.), The macroeconomics of populism in Latin America, University of Chicago Press, pp. 7-13.

ENGESSER, Sven; ERNST, Nicole; ESSER, Frank. \& BÜCHEL, F. (2017), "Populism and social media: How politicians spread a fragmented ideology". Information, Communication \& Society, 20, 8:1109-1126.

FERREIRA, Jorge. (2001), "O nome e a coisa: o populismo na política brasileira”, in FERREIRA, Jorge (org.), O populismo e sua história: debate e crítica, Rio de Janeiro, Civilização Brasileira, pp. 59-124.

FIGUEIREDO, Argelina \& LIMONGI, Fernando. (1999), Executivo e Legislativo na nova ordem constitucional. Rio de Janeiro, FGV.

FINCHELSTEIN, Federico. (2019), From fascism to populism in history. Berkeley, University of California Press.

FRENCH, John D. (2009), "Understanding the Politics of Latin America's Plural Lefts (Chavez/ Lula): Social democracy, populism and convergence on the path to a post-neoliberal world". Third World Quarterly, 30, 2:349-370.

GERMANI, Gino. (1971), Política y sociedad en una época de transición. Buenos Aires, Paidos.

GHERGHINA, Sergiu \& SOARE, Sorina. (2019), "Electoral performance beyond leaders? The organization of populist parties in postcommunist Europe”. Party Politics, 25, 5:649-651.

GOERTZ, Gary. (2006), Social Science Concepts: A User's Guide. Princeton University Press.

GOMES, Angela. (1996), "O populismo e as ciências sociais no Brasil”. Tempo, 1, 2:31-58.
GOMES, Angela. (2015), A invenção do trabalhismo. Rio de Janeiro, FGV.

GRIGERA, Juan. (2017), "Populism in Latin America: Old and new populisms in Argentina and Brazil". International Political Science Review, 38, 4:441-455.

GRIMMER, Justin \& STEWART, Brandon. (2013), "Text as data: the promise and pitfalls of automatic content analysis methods for political texts". Political Analysis, 21, 3:267-297.

HAWKINS, Kirk (2009), "Is Chávez populist? Measuring populist discourse in comparative perspective". Comparative Political Studies, 42, 8:1040-1067.

HAWKINS, Kirk (2010), Venezuela's Chavismo and Populism in Comparative perspective. Cambridge University Press.

HAWKINS, Kirk \& SELWAY, Joel, (2017). "Thaksin the Populist?”. Chinese Political Science Review, 2, 3: 372-394.

HAWKINS, Kirk \& KALTWASSER, Rovira C. (2017), "The Ideational Approach to Populism". Latin American Research Review, 52, 4:513-528.

HAWKINS, Kirk \& KALTWASSER, Rovira C. (2018), "Introduction: the ideational approach", in CARLIN, Ryan et al. (orgs.), The Ideational Approach to Populism: Concept, Theory, and Analysis, Londres, Routledge, pp. 1-23.

HAWKINS, Kirk; READ, Madeleine \& PAUWELS, Teun. (2017), "Populism and its causes", in KALTWASSER, Rovira C. (orgs.), The Oxford Handbook of Populism. Oxford University Press, pp. 267-286.

HEINISCH, Reinhard, \& MAZZOLENI, Oscar. (2016), "Comparing Populist Organizations", in HEINISCH, Reinhard, \& MAZZOLENI, Oscar, Understanding populist party organisation, Londres, Palgrave Macmillan, pp. 221-246.

HUNTER, Wendy \& POWER, Timothy. (2007), "Rewarding Lula: Executive power, social policy, and the Brazilian elections of 2006". Latin American Politics and Society, 49, 1:1-30.

HUNTER, Wendy \& POWER Timothy. (2019), "Bolsonaro and Brazil's Illiberal Backlash". Journal of Democracy, 30, 1:68-82. 
HUQ, Aziz \& GINSBURG, Tom. (2018),:How to Lose a Constitutional Democracy". UCLA Law Review, 65, 1:78-169.

IZUMI, Mauricio Yoshida. (2017), Velhas questôes, novos métodos: posiçóes, agenda, ideologia e dinheiro na política brasileira. Tese de Doutorado. Faculdade de Filosofia, Letras e Ciências Humanas da Universidade de São Paulo, São Paulo.

IZUMI, Mauricio \& MOREIRA Davi. (2018), "O texto como dado: desafios e oportunidades para as ciências sociais". Revista Brasileira de Informação Bibliográfica em Ciências Sociais BIB, 86, 2:138-174.

JAGERS, Jan \& WALGRAVE, Stefaan. (2007), "Populism as political communication style". European Journal of Political Research, 46, 3:319-345.

KALTWASSER, Romina Cristóbal; TAGGART, Paul; ESPEJO, Paulina O. \& OSTIGUY, Pierre (orgs.). (2017), The Oxford Handbook of Populism. Oxford University Press.

KATSAMBEKIS, Giorgos \& KIOUPKIOLIS Alexandros (orgs.). (2019), The Populist Radical Left in Europe. Londres, Routledge.

KEIL, André. (2020), “We need to rediscover our manliness...' The language of gender and authenticity in German right-wing populism". Journal of Language and Politics, 19, 1:107-124.

LACLAU, Ernesto. (1977), Politics and Ideology in Marxist Theory: Capitalism, Fascism, Populism. Londres, New Left Book.

LACLAU, Ernesto. (2005), On populist reason. Nova York, Verso.

LEVITSKY, Steven \& LOXTON, James. (2013), "Populism and competitive authoritarianism in the Andes". Democratization, 20, 1:107-136.

LUCAS, Christopher; NIELSEN, Richard A.; ROBERTS, Margaret E.; STEWART, Brandon M.; STORER, Alex \& TINGLEY, Dustin. (2015), "Computer-assisted text analysis for comparative politics”. Political Analysis, 23, 2:254-277.

MIGUEL, Luis Felipe \& FEITOSA Fernanda. (2009), "O gênero do discurso parlamentar: mulheres e homens na tribuna da Câmara dos Deputados”. Dados, 52, 1:201-221.
MOFFITT, Benjamin. (2015), "Contemporary Populism and 'The People' in the Asia-Pacific Region", in DE LA TORRE, Carlos. The Promise and Perils of Populism: Global Perspectives. Lexington, University Press of Kentucky, pp. 293-316.

MOFFITT, Benjamin \& TORMEY, Simon. (2014), "Rethinking populism: Politics, mediatisation and political style". Political Studies, 62, 2:381-397. MOLE, Richard. (2011), "Nationality and sexuality: homophobic discourse and the 'national threat' in contemporary Latvia". Nations and Nationalism, 17, 3:540-560.

MOREIRA, Davi. (2019), "Karaokê da Câmara dos Deputados: o uso do microfone na atividade parlamentar”. Opinião Pública, 25, 3:597-629. MOREIRA, Davi. (2020), "Com a palavra os nobres deputados: Ênfase temática dos discursos dos parlamentares brasileiros". Dados, 63, 1:1-37.

MOUFFE, Chantal. (2013), Agonistics: Thinking the world politically. Londres, Verso.

MUDDE, Cas. (2007), Populist Radical Right Parties in Europe. Cambridge University Press.

MUDDE, Cas. (org). (2017a), The populist radical right: A reader. Nova York, Routledge.

MUDDE, Cas. (2017b), "Populism. An Ideational Approach", in KALTWASSER, Romina Cristóbal et al. The Oxford Handbook of Populism. Oxford University Press, pp. 27-46.

MUDDE Cas \& KALTWASSER, Rovira Cristóbal (orgs.). (2012), Populism in Europe and the Americas. Cambridge University Press.

MUDDE, Cas \& KALTWASSER Rovira Cristóbal. (2013), "Exclusionary vs. inclusionary populism: Comparing contemporary Europe and Latin America". Government and Opposition, 48, 2:147-174.

MUDDE, Cas \& KALTWASSER, Rovira Cristóbal. (2017), Populism: A very short introduction. Oxford University Press.

MÜLLER, Jan-Werner. (2011), Contesting Democracy: Political Ideas in Twentieth-Century Europe. New Haven, Yale University Press.

MÜLLER, Jan-Werner. (2017), What is populism? Londres, Penguin. 
MUSSI, Daniela \& KAYSEL, André Velasco Cruz. (2020), "O populismo de Francisco Weffort". Revista Brasileira de Ciências Sociais, 35, 104:1-21.

NAGEL, Joane. (1998). "Masculinity and nationalism: Gender and sexuality in the making of nations". Ethnic and Racial Studies, 21, 2:242-269.

OLIVER, J. Eric \& RAHN, Wendy M. (2016), "Rise of the Trumpenvolk: Populism in the 2016 Election". The ANNALS of the American Academy of Political and Social Science, 667, 1:189-206.

PANIZZA, Francisco. (2000), "Neopopulism and its limits in Collor's Brazil". Bulletin of Latin American Research, 19, 2:177-192.

PANIZZA, Francisco. (2005), "Introduction: populism and the mirror of democracy", in PANIZZA, Francisco (org.), Populism and the Mirror of Democracy, Londres, Verso, pp. 1-31.

PAPPAS, Takis S. (2016), "Are populist leaders 'charismatic'? The evidence from Europe”. Constellations, 23, 3:378-390.

PASQUINO, Gianfranco. (2008), "Populism and Democracy”, in ALBERTAZZI, Daniele \& MACDONNELL, Duncan (orgs.), Twenty-first century populism. The spectre of Western democracy, Basingstoke, Palgrave McMillan, pp. 15-48.

PAUWELS, Teun. (2011), "Measuring populism: A quantitative text analysis of party literature in Belgium”. Journal of Elections, Public Opinion and Parties, 21, 1:97-119.

RENNÓ, Lucio. (2020), “The Bolsonaro Voter: Issue Positions and Vote Choice in the 2018 Brazilian Presidential Elections". Latin American Politics and Society, 62, 3:1-23.

RIBEIRO, Pedro Floriano. (2014), "An amphibian party? Organisational change and adaptation in the Brazilian Workers' Party, 1980-2012”. Journal of Latin American Studies, 46, 1:87-119.

ROODUIJN, Matthijs. (2014), “The mesmerising message: The diffusion of populism in public debates in Western European Media”. Political Studies, 62, 4:726-744.

ROODUIJN, Matthijs. (2019), "State of the field: How to study populism and adjacent topics? A plea for both more and less focus". European Journal of Political Research, 58, 1:362-372.
ROODUIJN, Matthijs; DE LANGE Sarah L. \& VAN DER BRUG, Wouter. (2014), “A populist Zeitgeist? Programmatic contagion by populist parties in Western Europe”. Party Politics, 20, 4:563-575.

ROODUIJN, Matthijs \& PAUWELS, Teun. (2011), "Measuring populism: Comparing two methods of content analysis". West European Politics, 34, 6:1272-1283.

RUTH-LOVELL, Saskia. P. (2018), "Populism and the erosion of horizontal accountability in Latin America”. Political Studies, 66, 2:356-375.

SAES, Decio. (1994), "A reemergência do populismo no Brasil e na América Latina", in DAGNINO, Evelina (org.), Os anos 90: Política e sociedade no Brasil, São Paulo, Brasiliense.

SALLES, Nara. (2019), "Programs and Parties: Rethinking Electoral Competition Through Analysis of Brazilian 'Grotōes'”. Brazilian Political Science Review, 13, 2:1-36.

SALLUM, Brasilio Jr. (2003), "Metamorfoses do Estado brasileiro no final do século XX". Revista Brasileira de Ciências Sociais, 18, 52:35-54.

SALLUM, Brasilio Jr. \& CASARÓES, Guilherme (2011), "O impeachment do presidente Collor: a literatura e o processo”. Lua Nova, 82:163-200.

SMITH, Amy Erica. (2020), "Covid vs. Democracy: Brazil's Populist Playbook”. Journal of Democracy, 31, 4:76-90.

STAVRAKAKIS, Yannis \& KATSAMBEKIS, Giorgos. (2014), "Left-wing populism in the European periphery: the case of SYRIZA". Journal of Political Ideologies, 19, 2:119-142.

STAVRAKAKIS, Yannis; KATSAMBEKIS, Giorgos; NIKISIANIS, Nikos; KIOUPKIOLIS, Alexandros \& SIOMOS, Thomas. (2017), "Extreme rightwing populism in Europe: revisiting a reified association”. Critical Discourse Studies, 14, 4:420-439.

TAGGART, Paul. (2017), "Populism in Western Europe", in KALTWASSER, Rovira Cristóbal et al. (orgs.), The Oxford handbook of populism, Oxford University Press.

TAMAKI, Eduardo Ryo \& FUKS, Mario. (2020), "Populism in Brazil's 2018 General Elections: 
an Analysis of Bolsonaro's Campaign Speeches". Lua Nova, s/v, 109:103-127.

TAROUCO, Gabriela da Silva \& MADEIRA, Rafael Machado. (2013), "Partidos, programas e o debate sobre esquerda e direita no Brasil". Revista de Sociologia e Política, 21, 45:149-165.

URBINATI, Nadia. (2013), "Crise e metamorfoses da democracia”. Revista Brasileira de Ciências Sociais, 28, 82:5-16.

URBINATI, Nadia. (2019), Me the people: How populism transforms democracy. Harvard University Press.

VAN DER BRUG, Wouter \& MUGHAN, Anthony. (2007). "Charisma, leader effects and support for right-wing populist parties". Party Politics, 13, 1:29-51.

VAN KESSEL, Stijn. (2015), Populist parties in Europe: Agents of discontent? Londres, Palgrave Macmillan.

WEFFORT, Francisco. (1989), O populismo na política brasileira. Rio de Janeiro, Paz e Terra.
WELBERS, Kasper; VAN ATTEVELDT, Wouter \& BENOIT, Kenneth. (2017), “Text analysis in R". Communication Methods and Measures, $11,4: 245-265$.

WEYLAND, Kurt. (2001), "Clarifying a contested concept: Populism in the study of Latin American politics". Comparative Politics, 34, 1:1-22.

WEYLAND, Kurt, (2003), "Neopopulism and Neoliberalism in Latin America: how much affinity?" Third World Quarterly, 24, 6:1095-1115.

WEYLAND, Kurt. (2017), "Populism: A PoliticalStrategic Approach", in KALTWASSER, Rovira Cristóbal et al. (orgs.), The Oxford Handbook of Populism. Oxford University Press, pp. 48-71.

WEYLAND, Kurt. (2020), “Populism's Threat to Democracy: Comparative Lessons for the United States". Perspectives on Politics, 18, 2:389-406. WILKERSON, John \& CASAS Andreu. (2017), "Large-scale computerized text analysis in political science: Opportunities and challenges". Annual Review of Political Science, 20:529-544. 


\section{O POPULISMO NO BRASIL (1985-2019): UM VELHO CONCEITO A PARTIR DE UMA NOVA ABORDAGEM}

\author{
Paolo Ricci, Maurizio Izumi, Davi \\ Moreira
}

Palavras-chave: populismo; Bolsonaro; análise do discurso; abordagem ideacional; nacionalismo

Nas últimas duas décadas, o conceito de populismo foi alvo de críticas nas ciências sociais brasileiras. Neste artigo, resgatamos sua importância para responder à seguinte pergunta: quão populistas são os presidentes brasileiros? Em linha com a abordagem ideacional, definimos o populismo como uma disputa entre dois grupos homogêneos e antagônicos: um "povo puro" e uma "elite corrupta”. Usando métodos mistos, classificamos 5.823 pronunciamentos oficiais de presidentes de José Sarney a Jair Bolsonaro (1985/2019). Os resultados apontam para a identificação de três presidentes populistas na nova república: Collor, Lula e Bolsonaro. Por fim, discutimos as diferenças entre os três e afirmamos que, no Brasil o populismo não é, por si só, uma ameaça à democracia.

\section{POPULISM IN BRAZIL (1985-2019): AN OLD CONCEPT FROM A NEW APPROACH}

\author{
Paolo Ricci, Maurizio Izumi, Davi \\ Moreira
}

Keywords: populism; Bolsonaro; discourse analysis; ideational approach; nationalism.

The concept of populism has been criticized in Brazilian social sciences in the last two decades. In this article, we rescue its importance to answer the following question: how populist are Brazilian presidents? In line with the ideational approach, we define populism as a dispute between two homogeneous and antagonistic groups: a "pure people" and a "corrupt elite". In this context, we used mixed methods to classify 5,823 official statements by presidents from José Sarney to Jair Bolsonaro (1985/2019). The results point to the identification of three populist presidents in the new republic: Collor, Lula and Bolsonaro. Finally, we discuss the differences between the three and affirm that, in Brazil, populism is not, in itself, a threat to democracy.

\section{LE POPULISME AU BRÉSIL (1985-2019): UN CONCEPT ANCIEN À PARTIR D'UNE NOUVELLE APPROCHE}

\author{
Paolo Ricci, Maurizio Izumi, Davi \\ Moreira
}

Mots-clés: populisme; Bolsonaro; analyse du discours; approche idéationnelle; nationalisme.

Au cours des deux dernières décennies, le concept de populisme a été la cible de critiques au sein des sciences sociales brésiliennes. Cet article remet en valeur son importance pour répondre à la question suivante: quel est le degré de populisme des présidents brésiliens ? Dans le sillage de l'approche idéationnelle, le populisme est envisagé comme une dispute entre deux groupes homogènes et opposés: un " peuple pur " et une " élite corrompue ». 5823 discours officiels des présidents allant de José Sarney à Jair Bolsonaro (1985/2019) ont été classés sur la base de méthodes mixtes. Les résultats identifient trois présidents populistes dans la nouvelle République: Collor, Luis Ignacio da Lula Silva et Bolsonaro. Partant de là, l'analyse de la différence entre les trois montre qu'au Brésil, le populisme n'est pas en soi une menace contre la démocratie. 
Apêndice A - Neste apêndice apresentamos o dicionário-base criado para a identificaçáo das frases populistas nos discursos presidenciais.

Tabela 2

Palavras-chave que indicam elementos potencialmente populistas

\section{Palavras-chave relativas a povo}

"amiga", "amigas”, "amigo”, "amigos”, "brasileiras, "brasileiros”, “classe média”, "classe popular”, "cristâ", "cristão”, “cristãos”, “cristãs”, "família”, "Nordeste”, "nordestina”, "nordestinas”, "nordestino”, “nordestinos”, "Norte”, "pobre”, "pobres”, “pobreza”, "povo", "trabalhador", "trabalhadora", "trabalhadoras", "trabalhadores"

\section{Palavras-chave relativas a elite}

"aquecimento global”, "ambiental”, "ambientalista”, "ambientalistas”, "banco", "bancos", "banqueiro", "banqueiros”, "bandeira”, "classe alta”, "classe política”, "comunismo”, "comunista”, "comunistas”, "corrupção”, "corrupta”, "corruptas”, "corrupto”, “corruptos”, "direita”, “direitista”, "demagogia”, "dinheiro”, “ditadura”, "elite”, "elites”, “empreendedor”, "empreendedora”, “empreendedoras”, “empreendedores”, “empresária”, “empresarial”, “empresárias”, “empresário”, “empresários”, “esquerda”, "esquerdista”, "Estado”, "gay”, "gays”, "globalista”, "globalistas”, “ideologia”, “ideologias”, “ideológico”, “índio”, “índios”, “inimigo", "lgbt”, “maraja”", "marajás”, "mercado,” “minoria”, “minorias”, "ong”, "pátria”, "petista”, "petistas”, "petralha”, “petralhas”, “populismo”, “privilegiada”, “privilegiadas”, “privilegiado”, “privilegiados”, "privilégio”, “privilégios”, “PT”, "rica”, "ricas", "rico", "ricos”, "setor privado", "setor público", "socialismo”, "socialista”, "socialistas”, "Sudeste”, "Sul”, "totalitarismo", "viés ideológico"

O primeiro conjunto de palavras refere-se diretamente à dimensão em que o populista se coloca ao lado da populaçáo. Em especial, elas buscam captar a dimensão de classe associada ao discurso populista, que contrapóe o povo à elite; questóes regionais são acionadas particularmente no governo Lula, presidente que se colocava em uma posição favorável aos interesses das populaçóes das regióes Norte e Nordeste. Já o segundo conjunto de palavras refere-se à dimensão em que o populista se contrapóe ao inimigo do povo. Em geral, utilizam-se termos que aludem ao conflito entre ricos e pobres, classe trabalhadora e elite empresarial. Além disso, foram incluídos diversos termos que não só têm polarizado as posições entre progressistas e conservadores no período recente, mas também têm sido exploradas em discursos de presidentes populistas conservadores com o intuito de "demonizar" a oposição progressista. 
Apêndice B - Neste apêndice apresentamos alguns exemplos de frases classificadas como populistas ou não populistas. Para exemplificar estas frases, selecionamos aquelas encontradas nos discursos de Collor, Lula e Bolsonaro, isto é, os três presidentes classificados como populistas. As frases selecionadas contêm alguma referência a palavras-chaves relativas a povo e/ou elite, de acordo com o dicionário apresentado no Apêndice A.

Tipo 1. Frases populistas que fazem referência ao povo (valorizando-o) e à elite (criticando-a) ao mesmo tempo:

"Minha eleição representou o endosso majoritário da sociedade brasileira ao meu projeto de redefinição do papel do Estado e de revigoramento das forças de mercado, mas representou ao mesmo tempo o apoio ao meu compromisso com a maioria pobre, com as classes trabalhadoras" (discurso de Fernando Collor por ocasião das comemoraçóes do Dia do Trabalho no Tribunal Superior do Trabalho. Brasília, lo de maio de 1990).

"A verdade é que normalmente nós somos eleitos pelos mais pobres mas quando a gente ganha as eleiçóes quem tem acesso ao gabinete dos dirigentes não são os mais pobres; são os mais ricos" (discurso de Luiz Inácio Lula da Silva na cerimônia de abertura do Diálogo Brasil-África sobre Segurança Alimentar, Combate à Fome e Desenvolvimento Rural. Palácio Itamaraty, Brasília, 10 de maio de 2010).

"Graças a Deus, o povo aqui acordou e em parte se mirou no que acontecia negativamente em seu país e resolveram dar um ponto final no populismo, na demagogia barata, que leva exatamente a situação que o seu país se encontra no momento" (discurso de Jair Bolsonaro após se reunir com o autoproclamado presidente da Venezuela, Juan Guaidó. Palácio do Planalto, Brasília, 28 de fevereiro de 2019).

Tipo 2: não populista: favorável ao povo mas sem fazer referência à elite:

"Sinto-me feliz pela oportunidade de vir a São Paulo para expressar o meu apreço e admiração pelo povo deste estado e desta cidade que tanto tem contribuído para o progresso do Brasil e para o meu Projeto de Reconstrução Nacional, que tem como um de seus pilares a confiança no talento e na determinação dos trabalhadores e empresários do setor privado de nossa economia" (discurso de Fernando Collor na cerimônia de entrega de prêmios da revista Exame. São Paulo, 30 de agosto de 1990).

"Dinheiro público bom é aquele que está aplicado em obras, gerando riquezas para este País, gerando melhoria da qualidade de vida do nosso povo" (discurso de Luiz Inácio Lula da Silva, na cerimônia de lançamento do PAC de saneamento e urbanização no Ceará. Fortaleza, 3 de julho de 2007).

"Estamos mostrando com gestos, com palavras e com açóes, que nós, políticos, devemos fidelidade absoluta ao povo e nada mais além disso" (discurso de Jair Bolsonaro em cerimônia de lançamento do Programa Médicos pelo Brasil. Palácio do Planalto, Brasília, 10 de agosto de 2019)

Tipo 3: Não populista, quando é contra a elite mas não faz referência ao povo:

"O processo de emagrecimento do Estado, retirando gorduras desnecessárias ao seu funcionamento, é uma medida determinante do sucesso do nosso programa econômico" (discurso de Fernando Collor, Palácio do Planalto, Brasília, 27 de março de 1990).

"Não é aquela briga raivosa, é aquela briga de companheiro, de fazer os países ricos entenderem que nós não queremos viver de favores, que nós queremos apenas competir, que nós queremos concluir o acordo da Rodada de Doha, que não foi concluído por conta das eleiçóes americanas e das eleiçôes na Índia e está parado há dois anos" (discurso de Luiz Inácio Lula da Silva no Fórum Empresarial Brasil-África do Sul. Johanesburgo, África do Sul, 9 de julho de 2010).

"Tivemos aqui a questão da liberação do FGTS, a questão da antecipação do $13^{\circ}$ para os servidores, o 13을 até, do Bolsa Família, sem aumentar a despesa, que vem fruto de combate à corrupção” (discurso de Jair Bolsonaro, durante cerimônia de lançamento do IPCA para Crédito Imobiliário. Palácio do Planalto, Brasília, 20 de agosto de 2019). 